\title{
Non-coaxial heterogeneous deformation in the Num orthogneiss (Arun valley, Mt. Makalu area, eastern Nepal)
}

\author{
R Carosi ${ }^{1 *}$, C Frassi $^{1}, C_{\text {M Montomoli }}{ }^{1}$ PC Pertusati ${ }^{1}$, C Groppo ${ }^{2}$, F Rolfo ${ }^{2}$ and D Visonà ${ }^{3}$
}

1 Department of Earth Sciences, University of Pisa, Via S. Maria, 53 I-56126 Pisa, ITALY

2 Department of Mineralogical and Petrological Sciences, University of Torino, Via Valperga Caluso 35, I-10125 Torino, ITALY

3 Department of Mineralogy and Petrology, University of Padova, c.so Garibaldi 3735122 Padova, ITALY

* For correspondence, email: carosi@dst.unipi.it

In the Arun and Barun valleys the upper portion of the Lesser Himalayan section is made up by the Num orthogneiss. It is a 3-4 km thick unit of granitic augen gneiss with bands of kyaniteflogopite schists (Lombardo et al. 1993). It records a noncoaxial deformation related to its involvement within the Main Central Thrust zone that produced an heterogeneous mylonitic deformation with rotated feldspar porphyroclasts, bookshelf structures and localized shear bands with a prominent top-to-the SW sense of shear. The base of the Num orthogneiss is the Main Central Thrust I (MCT I, sensu Arita 1983).

Micaschists and/or micaceous levels are often intercalated within the Num orthogneiss, being parallel to the mylonitic foliation. Two different kinds of micaceous levels have been recognized:

- Type a: derived from sedimentary levels deformed and transposed within the orthogneiss. They often contain garnet and could be referred to Kushma and/or Seti Formations (Goscombe and Hand 2006);

- Type b: decimetric- to metric-thick micaceous levels with the same mineral assemblage as in the orthogneiss but showing a strong grain size reduction and mica enrichment along the main foliation.
In Type b levels strain increases from the mylonitic orthogneiss toward the micaceous levels as highlighted by strong grain size reduction of feldspar crystals and development of polycristalline quartz ribbons; small-size tourmaline crystals are still present.

A conspicuous enrichment in muscovite and biotite has been observed along the shear planes and sometimes gneiss is transformed into phyllonites.

Microstructural studies revealed that many of the micaceous intercalations within Num orthogneiss are the product of the localization of non-coaxial deformation during the evolution of deformation in the MCT zone.

References

Arita K. 1983. Origin of the inverted metamorphism of the Lower Himalayas, Central Nepal. Tectonophysics 93: 43-60

Goscombe B and M Hand. 2006. Gondwana Research 10: 232-255

Lombardo B, P Pertusati and A Borghi. 1993. Geology and tectono-magmatic evolution of the eastern Himalaya along the Chomolungma-Makalu transect. In: Treloar P J and Searle M P: (eds.) Himalayan Tectonics Geological Society, London Special Publication 74: 341-355 